\title{
Factors Influencing Chinese Tourists to Travel to Thailand
}

\author{
Dr. Watchara Yeesoontes, Khunping Wu \\ Postgraduates school of business administration Kasembundit University, Bangkok \\ watchara.yee@kbu.ac.th
}

\begin{abstract}
The purpose of this study is to determine the factors and behavior that influencing Chinese tourists to travel to Thailand. The Chinese tourists were 385 people by using a check list and rating scale questionnaire as a tool. Statistical application used for data analysis was percentage, mean, standard deviation, Chi-Square, and regression analysis.

Findings indicated that most of respondents were females, age 21-30 years old, bachelor degree graduated, students and college students, average monthly income 5,000 baht, and traveled in Thailand 1.4 time yearly. The reasons that Chinese tourists who traveled to Thailand were entertaining, pleasure and received tour information from the Internet, preferred to stay at the hotel, friends influenced to make the decision, and traveled by themselves. The overall picture of the opinions of marketing mix factors that influencing Chinese tourists to travel to Thailand were in high level as the following details, such as a variety of tours and services with convenient to travel, safety, and appropriate prices for accommodation, reasonable prices for foods, and admission fee, more convenient to buy tour packages in different channel, and receive discount prices from tour companies. The test of hypothesis revealed that marketing mix, such as marketing promotion, special packages price promotion which correlated with Chinese tourists' behavior to travel to Thailand at significant level 0.05 .

Recommendations from this study were that tour companies should guide tourists to a variety of places, contact center to assist tourists who need help, service with courtesy, reasonable tour packages, healthy foods, purchase package tour through Internet for example, nationwide tour agencies, offers family packages with bargaining prices, and alliance with businesses that involved with traveling.
\end{abstract}

Keyword: Factors Influencing Travel

\section{Introduction}

Tourism is an industry that plays an important role in the country's economic and social development. Because of the tourism bring revenue to the country several million per year. There is also a trend to more important role in the future. Also International tourism can bring revenue from foreign currency to solve the country deficit that derived from trade deficit. Domestic tourism portion will help stimulate investment and services to help create jobs, career, and income redistribution toward every level of occupation. Therefore, it requires attention to develop and promote tourism to become the tourism industry that can meet the demand of tourism effectively, and to attract foreign tourists to visit Thailand and bringing the revenue from tourism to develop the country make progress and prosperity (Bunlert Jittungwattana, 2548).

Tourism is an industry that plays an important role in the country economic and social development. It's not only generate revenue number one value of trade in services of the country but also contributes to many businesses, such as hotels, restaurants, souvenir shops, and transportation, etc., which cause the investment, employment and income distribution to the local areas each year. In year 2014, tourism can generate revenue in amount of 2345.1 million baht, accounted for 19.3 percent of GDP. Tourism 
contributes to the employment of over 2 million jobs. Currently, tourism industry are the main industry of the country which earning in both foreign and domestic currency. Government realizes the important of tourism in term of promoting and give priority to seriously develop tourism industry by action plan continuously.

Chinese tourists have been expanded rapidly, due to China economic growth continuously, as a result people in China have increased buying power combine with the Chinese government has eased regulations on travel to foreign countries for example, allowed to take more foreign currency out of the country, allow Chinese to travel or visit relatives in foreign countries without buying tour packages from tour agencies, and approved destination status to more countries.

Presently, Chinese tourists plays an important role of the tourism sector in many countries because China is a country that spending on foreign travel as high as the world top travel abroad each year. It is also expected that Chinese tourists traveling abroad has increased from 82 million in 2555 to 100 million people within a few year which accounted for 13 percent of the population of China approximately 200 million people, combined with the trend of economic growth in China continued at a rate of 7 percent per year.

Thailand considered the tourist market that has potential to compete with other countries because Thailand has tourist attractions and natural resources, such as coastal area, beaches, forest, water falls, and comfortable climates. In addition, Thailand has a cultural tradition that included in each region of the country and the country are not too far from mainland China.

As introduction above, researcher are interested in studying Chinese tourists' behavior that traveled to Thailand. Use the results from this study as a guideline on management of tourism services in order to satisfy the need of Chinese tourists that will come to Thailand.

\section{The purpose of the study}

1. To study Chinese tourists behavior who traveled to Thailand.

2. To study factors that affecting Chinese tourists who traveled to Thailand.

\section{Research Methodology}

The samples were 385 Chinese tourists who traveled to Thailand.

\section{Data collection procedure}

The questionnaires were distributed to sample of 385 Chinese tourists who traveled to Thailand. A total of 385 usable questionnaires were returned back to the researcher, yielding a 100 percent response rate and no missing data.

Findings revealed the information of marketing mix factors affecting Chinese tourists' behavior who traveled in Thailand.

The overall pictures of the factors that influencing Chinese tourists' behavior to travel to Thailand. 


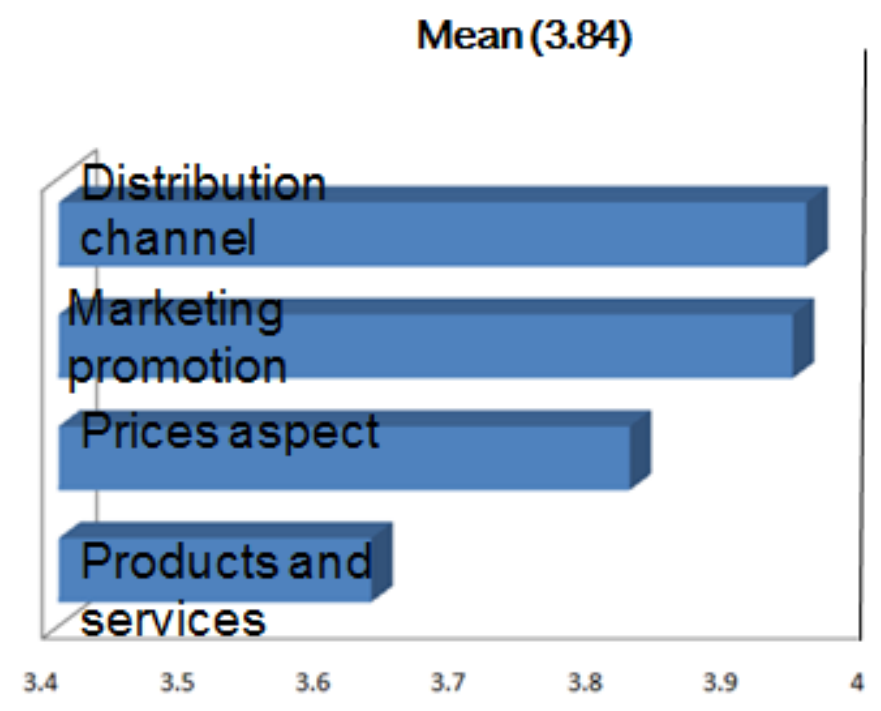

Fig. 1

From figure 1 shows overall picture of marketing mix

Finding revealed that the overall picture of the important factors influencing Chinese tourists to travel to Thailand comprised of 4 aspects with high level of the opinions ( $\bar{x}=3.84)$ as following reasons, distribution channel $(\bar{x}=3.97)$, marketing promotion $(\bar{x}=3.94)$, prices $(\bar{x}=3.82)$, and products and services $(\bar{x}=3.63)$.

The comparison of correlation between marketing mix with Chinese tourists' behavior to travel to Thailand.

\begin{tabular}{|c|c|c|c|c|c|c|}
\hline \multirow[t]{2}{*}{ Factors influencing Chinese tourists to travel to Thailand } & \multicolumn{2}{|c|}{$\begin{array}{l}\text { Unstandardized } \\
\text { Coefficients }\end{array}$} & \multirow{2}{*}{$\begin{array}{c}\text { Standardiz } \\
\text { ed } \\
\text { Coefficien } \\
\text { ts }\end{array}$} & \multirow[t]{2}{*}{$\mathrm{t}$} & \multirow[t]{2}{*}{ Sig. } & \multirow[t]{2}{*}{ results } \\
\hline & B & $\begin{array}{l}\text { Std. } \\
\text { error }\end{array}$ & & & & \\
\hline (Constant) & .643 & .368 & & 1.750 & .084 & \\
\hline \multicolumn{7}{|c|}{ Products and services } \\
\hline 1. Variety of tour places & -.019 & .140 & -.026 & -.132 & .895 & $\begin{array}{c}\text { Not } \\
\text { relate }\end{array}$ \\
\hline 2. $\quad$ Tour places with convenient & -.048 & .129 & -.064 & -.368 & .811 & $\begin{array}{c}\text { Not } \\
\text { relate }\end{array}$ \\
\hline 3. Famous tour places & .060 & .094 & .085 & .637 & .526 & $\begin{array}{c}\text { Not } \\
\text { relate }\end{array}$ \\
\hline 4. Safe tour places and accommodations & .028 & .122 & .038 & .231 & .818 & $\begin{array}{c}\text { Not } \\
\text { relate }\end{array}$ \\
\hline \multicolumn{7}{|c|}{ Prices aspect } \\
\hline 1. Appropriate prices of accommodations & -.133 & .131 & -.172 & -1.015 & .313 & $\begin{array}{c}\text { Not } \\
\text { relate }\end{array}$ \\
\hline 2. Appropriate prices of tour places & .229 & .128 & .313 & 1.784 & .078 & $\begin{array}{c}\text { Not } \\
\text { relate }\end{array}$ \\
\hline 3. Appropriate for transportation fairs & .217 & .145 & .268 & 1.495 & .138 & $\begin{array}{c}\text { Not } \\
\text { relate }\end{array}$ \\
\hline 4. Appropriate for food prices & -.269 & .148 & -.354 & -1.824 & .071 & $\begin{array}{c}\text { Not } \\
\text { relate }\end{array}$ \\
\hline \multicolumn{7}{|c|}{ Distribution channel } \\
\hline 1. Buy tour packages through Internet & .017 & .167 & .021 & .102 & .919 & $\begin{array}{c}\text { Not } \\
\text { relate }\end{array}$ \\
\hline
\end{tabular}




\begin{tabular}{|c|c|c|c|c|c|c|}
\hline \multirow{2}{*}{ Factors influencing Chinese tourists to travel to Thailand } & \multicolumn{2}{|c|}{$\begin{array}{l}\text { Unstandardized } \\
\text { Coefficients }\end{array}$} & \multirow{2}{*}{$\begin{array}{c}\begin{array}{c}\text { Standardiz } \\
\text { ed } \\
\text { Coefficien } \\
\text { ts }\end{array} \\
\text { Beta }\end{array}$} & \multirow{2}{*}{$\mathrm{t}$} & \multirow{2}{*}{ Sig. } & \multirow{2}{*}{ results } \\
\hline & B & $\begin{array}{l}\text { Std. } \\
\text { error }\end{array}$ & & & & \\
\hline 2. $\quad$ Buy tour packages by using credit cards & .157 & .175 & .191 & .898 & .372 & $\begin{array}{c}\text { Not } \\
\text { relate }\end{array}$ \\
\hline 3. Easy to purchase tour packages from agent & .094 & .155 & .120 & .605 & .547 & $\begin{array}{c}\text { Not } \\
\text { relate }\end{array}$ \\
\hline 4. Be able to reservation a tour event with agent & -.093 & .134 & -.127 & -.698 & .487 & $\begin{array}{c}\text { Not } \\
\text { relate }\end{array}$ \\
\hline \multicolumn{7}{|c|}{ Marketing promotion } \\
\hline 1. Tour discount prices book & .117 & .131 & .154 & .893 & .374 & $\begin{array}{c}\text { Not } \\
\text { relate }\end{array}$ \\
\hline $\begin{array}{l}\text { 2. Advertising of tour places with happiness aims } \\
\text { for competition }\end{array}$ & -.157 & .129 & -.202 & -1.223 & .224 & $\begin{array}{c}\text { Not } \\
\text { relate }\end{array}$ \\
\hline 3. Special tour prices with giveaways & -.441 & .170 & -.580 & -2.599 & .011 & related \\
\hline 4. Special tour promotion for attraction & .388 & .175 & .505 & 2.210 & .030 & related \\
\hline $\begin{array}{l}\text { 5. Special tour prices when purchased with } \\
\text { require amount by shopping center }\end{array}$ & .041 & .137 & .057 & .302 & .763 & $\begin{array}{c}\text { Not } \\
\text { relate }\end{array}$ \\
\hline
\end{tabular}

*Significant level 0.05

**Significant level 0.01

The comparison of correlation between marketing mix and Chinese tourists' behavior to travel to Thailand revealed that factors of marketing mix of distribution channel aspect regarding special packages tour with giveaway $(\mathrm{Sig} .=0.011)$, special promotion events to attract tourists $(\mathrm{Sig} .=0.030)$ were related to Chinese tourists behavior to travel to Thailand at significant level 0.05 .

\section{Summary of the study}

The purpose of this study is to determine the factors and behavior that influencing Chinese tourists to travel to Thailand. The Chinese tourists were 385 people by using a check list and rating scale questionnaire as a tool. Statistical application used for data analysis was percentage, mean, standard deviation, Chi-Square, and regression analysis. From data analysis results can be summarized as follow:

The results from data analysis of marketing mix factors affecting Chinese tourists behavior to travel to Thailand revealed that the average picture of opinions of marketing mix affecting Chinese tourists who traveled to Thailand were at high level consisted of all aspects, such as distribution channel, marketing promotion, prices, and tour packages and services, respectively.

Tour packages and services: from the study found that overall picture of the opinions of factors affecting Chinese tourists who traveled to Thailand as tour packages and services aspect were in high level, such as a variety of tour places, tour places area with convenient, safely famous tour places area and accommodations, respectively.

Prices aspect: from the study found that overall picture of the opinions of factors affecting Chinese tourists who traveled to Thailand as prices aspect were in high level, such as appropriate accommodations, services, admission fee of tour places, transportations, and foods, respectively.

Distribution channel aspect: from the study found that overall picture of the opinions of factors affecting Chinese tourists who traveled to Thailand as distribution channel aspect were in high level, such as be able to buy tour packages through e-commerce and shopping centers, can pay with credit cards, purchase tour packages from tour agent everywhere, reservation for the tour events, respectively.

Marketing promotion aspect: from the study found that overall picture of the opinions of factors affecting Chinese tourists who traveled to Thailand as marketing channel aspect were in high level, such 
as discount coupon, advertising with happiness tour as a main impression, special tour packages with giveaways, and special tour packages prices when purchased with the limited, respectively.

\section{Recommendation of the study}

Recommendations from this study were that tour companies should guide tourists to a variety of places, contact center to assist tourists when they need help, service with courtesy, reasonable tour packages, healthy foods, purchase package tour through Internet for example, nationwide tour agencies, offers family packages with bargaining prices, and alliance with businesses that involved with traveling.

\section{Suggestions to further study}

Suggestion for future study that should study with different group of tourists who travel from different countries besides China in order to improve the services to meet consumer requirement.

\section{References}

[1] Boonlert Jittanwattana. (2548). Tourism industry. Thammasart University publishing, Bangkok.

[2] Sivarit Ponsakornrangsilp. (2547). Principle of marketing. Top publisher, Bangkok.

[3] Anuwat Supachutikul \& Associate. (2541). Services quality.

[4] Peerasit Kumnuensil. (2541). Services quality.

[5] Gronroos (1990) Service management and marketing: Managing the moments of truth in service competition. Lexington, Mass: Lexington Books

[6] Parasuraman, Zeithaml\& Berry (1988) SERVQUAL: A Multi-item Scale for Measuring Consumer Perception of Service Quality. Journal of Retailing, 64(1), 12-40.

[7] Buzzell \& Gale (1987) The PIMS Principles: Linking Strategy and Performance. Free Press, New York.

[8] Thongchai Santivong. (2546). Consumer behavior on marketing. Chulalongkorn University publisher, Bangkok.

[9] Apisit Chattananon. (2547). Marketing Management, teaching manuel. NIDA, Bangkok.

[10] Saeri Vongmonta. (2542). Consumer behavior. Chulalongkorn University. Bangkok.

[11] Saritip Kavanobe. (2554). Motivation and Thai tourists behavior, capital district, Nan Province.

[12] Kanittarin Jinovat. (2550). Service quality of green leave hotel in southern area, Thesis, Valailak University.

[13] O'Neill and Charters (2006) Investigating the Effects of Consumer Experience Tourism on Brand Equity and Market Outcomes: an Application in the Wine Industry 